\title{
MANAGEMENT OF A PROJECT MANAGER'S COMPETENCES IN PUBLIC ORGANIZATIONS
}

\author{
[Řízení kompetencí projektového manažera ve veřejných organizacích] \\ Monika Chobotová ${ }^{1}$, Žaneta Rylková ${ }^{2}$ \\ ${ }^{1}$ Silesian University in Opava, School of Business Administration in Karvina, Univerzitní nám. 1934/3 \\ 73340 Karviná, Czech Republic \\ Email:rylkova@opf.slu.cz \\ ${ }^{2}$ Silesian University in Opava, School of Business Administration in Karvina, Univerzitní nám. 1934/3 \\ 73340 Karviná, Czech Republic \\ Email:chobotova@opf.slu.cz
}

\begin{abstract}
Nowadays, there is an increasing number of projects that are created and managed in public organizations. For this reason there is a need to develop managerial competencies (knowledge, skills, and attitudes) for project managers. This issue has been paid little attention so far, especially in terms of competencies necessary for team leadership and management of stakeholders. Competency models are created based on selected competencies and also depending on which aspect of the model is determined. The paper provides a theoretical perspective on the issue of managerial competencies. The article provides a theoretical perspective on the issue of managerial competencies and presents the results obtained from the survey, which was conducted in public organizations in the MoravianSilesian Region. The aim of the research was to reveal the current profile of project managers in the area managerial competencies. The managerial competence was created by three elements Competence, Commitment and Contribution.
\end{abstract}

Keywords: competency model, management, public organization, talent.

JEL classification: $\mathrm{H} 1, \mathrm{M} 12$

Doručeno redakci: 18.8.2014; Recenzováno: 27.8.2014; 2.9.2014; Schváleno k publikování: 27.5.2015

\section{Introduction}

Currently, we often encounter the position of a project manager in private and public organizations. The creation of this post is associated with the use of funds from the European Union. Projects are increasingly intervening in the most diverse areas, their number is rising and they are complex and diverse. Requirements for the competence of managers and team members are still significant and demanding. The correct identification of competencies is crucial to create the right competency model. This will serve to develop managers and increase organizational performance. A competency model is rooted in the organization that will be designated. The organization can be founded with a model that will be used for all employees or just for a particular position. This paper deals with testing the staff who works as a project manager in public organizations. The paper presents the results of the survey focused on the public organization working with competence. The article presents the first stage results of the survey which was carried out in public organizations of the Moravian Silesian Region.

\section{Theoretical Background Managerial Competency}

The term competency was probably first introduced to psychology literature in 1973 when David McClelland argued in his article 'Testing for competence rather than for intelligence' that traditional tests of academic aptitude and knowledge content in fact predicted neither job performance nor success in life. Thus, the quest for theory and tools that could reliably predict 
effectiveness in the workplace began McClelland (1973, p. 1-14). McClelland suggested the competency movement as an alternative to the trait (personal characteristics) and intelligence approaches to measuring and predicting human performance.

The next landmark in establishing the competency movement appears to be Boyatzis (1982). As is well-known, before competency analysis, the technique of job /analysis had extensively been used to create job descriptions. Boyatzis realized that when a manager is selected, often he or she is selected on the basis of a mental model (rather than an empirical model) of a "good" manager.

Ellström (1997) identified five meanings of competence:

1. competence as an attribute of the individual or their potential capacity to successfully handle a certain situation,

2. competence as job requirements or the prescribed qualifications required of the job,

3. competence-in-use or the competence used by the individual in performing the job,

4. competence as adaptation (identify competence by the successful performance of certain tasks that the individual cannot change or improve) or competence as developed (competence as the capacity to reflect and act),

5. change-oriented human competence (competence as cognitive-rational or intuitivecontextual).

Commission of the European Communities (2005) competence includes:

- cognitive competence involving the use of theory and concepts, as well as informal tacit knowledge gained experientially;

- functional competence (skills or know-how), those things that a person should be able to do when they are functioning in a given area of work, learning or social activity;

- personal competence involving knowing how to conduct oneself in a specific situation;

- ethical competence involving the possession of certain personal and professional values.

Armstrong, Stephens (2008) perceive the managerial competence as:

- any individual characteristic that can be measured or counted reliably and that can demonstrate significant distinction between effective and ineffective performance,

- basic skill and have facility needed for good work performance,

- all personal traits related to the work, knowledge, skills and values which encourage people to doing their job well.

According to Draganidis, Mentzas (2006, p. 51-64) the competency approaches were expected to help to identify the skills, knowledge, behaviours and capabilities needed to meet current and future personnel selection needs, in alignment with variations in strategies and organizational priorities and to focus the individual and group development plans to eliminate the gap between the competencies requested by a project, job role, or enterprise strategy and those available.

According to Horton, Hondeghem, Farnham (2002) the introduction of competency management is clearly linked with the organisational and culture changes which occurred on the all levels of management. The vertical integration is linked with competency management and with the vision and a strategy of the organization and there is also a horizontal integration as competencies link different processes of Human Resource Management. The strategic horizontal integration does not only mean coherence between HR policies and practices, 
however it also fits between internal resources and opportunities. The organization needs to have a strong communication strategy in place to ensure that employees understand the reason for implementing the competency model and the way it can help contribute to results.

\section{Competency model for project management}

Assessment of competencies is one thing, but the ultimate goal of the project or program manager is a success. The project manager must know how to lead their subordinates, must be able to decide correctly in every situation that may arise project management. Every manager should be able to correctly identify the need for further development and that can take advantage of the competency model. The competency model is a tool for detection and identification of needs for its development. The models managerial competences in many organizations have become an important part of human resources management.

According Ennis (2008) competency models provide information about the employee's performance and the necessary knowledge and skills received and acquired during the adaptation period. Define the level of competence which the renderer must prove at the end of the adaptation period. The adaptation period allows employers of the public organization to recognize whether an applicant is eligible to work in another company along with the potential for career growth.

In the professional literature we can read about the different competency models that are designed for project managers. International Project Management Association ${ }^{1}$ divided competence project manager into three parts: Behavioural competences, Technical and Contextual competences. The Levin-Ward (2011) has defined the competency of project manager as follows:

- Competence - A cluster of related knowledge, attitudes, skills, and other personal characteristics that affects a major part of one's job (i.e., one or more key roles or responsibilities), correlates with performance on the job, can be measured against well-accepted standards, and can be improved by means of training and development.

- Knowledge - Knowing something with the familiarity gained through experience, education, observation, or investigation. It is understanding a process, practice, or technique, or how to use a tool".

- Skill - Ability to use knowledge, a developed aptitude, and/or a capability to effectively and readily execute or perform an activity.

Project management competencies are achieved by the combination of education and the knowledge acquired during training, the skills developed through experience, and the application of such acquired knowledge and experience.

According to Gareis, Huemann, Martinuzzi (2013) the project management competency is the capability to manage projects professionally, by applying best practices regarding the design of the project management process, and the application of project management methods. Project management competencies require knowledge and experience in the subject, which enables the project to meet its deadlines and objectives.

Whiddett and Hollyford (2003) define managerial competencies as "sets of behaviours that enable individuals demonstrate the effective performance of tasks within the organization."

\footnotetext{
${ }^{1}$ http://ipma.ch/
} 


\subsection{Competence and talent management}

Talent is a renewable, but not inexhaustible, resource, and the market for top talent is increasingly competitive. According to Morel-Curran, (2008) demographic changes, education shortages, and global labor movement are some of the challenges facing organizations in the war for talent.

Orr, Sneltjes, Dai (2010) underline that the tension between supply and demand for talent creates a compelling case for strategic human resources (HR) - a discipline involving the deliberate and strategic selection, development, deployment, and recognition of top talent. Management competencies regard the competence as the heart of Talent Management. Competences act as the common denominator that helps bind and integrate processes in the selected organization. Some experts regard as a talent such an extraordinarily competent employee with a high potential who can significantly influence the organization's performance; moreover they think that talent management concerns only key individuals that is competent people heading for holding higher or top posts. An important step that the organization has to take in talent management is to identify key competences of the organization.

Competence refers to the knowledge, skills, and values required for today's and tomorrow's jobs. Without commitment, competence is discounted. Highly competent employees who are not committed are smart but don't work very hard. But employees may be competent (able to do work) and committed (willing to do work), but unless they are making a real contribution (finding meaning and purpose in their work). Contribution occurs when employees feel that their personal needs are being met through their active participation in their organization. These three terms are multiplicative, not additive. Talented employees must have skills, wills, and purpose according to Ulrich, Smallwood (2012).

I. Competence is interpreted as a more or less specialized system of abilities, proficiencies or skills, which enables a person, team or organization to act and react when completing concrete and familiar as well as novel working tasks according to Weinert, (2001):

- Flexibility - ability to adapt and work effectively in various and changing situations and activities in a team. The ability to anticipate and respond to changing circumstances, individuals or groups.

- Team working - ability to co-operate with others, directed at accomplishing the team objectives. It involves honest and open attitude connected with respect for all human values.

- Leadership - is generally described as a sense of responsibility and sense of mission in a long-term perspective, assertiveness and being oriented at achieving the objectives of a team. Leaders are able to focus on development of the team; they change the system in a creative way and inspire others to undertake actions.

- Lifelong learning means the skill to acquire new qualifications constantly, selfdevelopment, the use of one's own experience, skills to draw conclusions from mistakes.

- Communication - comprises written and verbal communication, but also listening skills and proper application of all available communication tools. Moreover, it involves understanding of communication differences, identifying factors which may become a barrier for a team's success. Communicating is essential for clear passing assignments and providing instructions for the team. 
- Analytical thinking - refers to the need to develop understanding of a situation or problem by breaking it down into component parts, or by tracing the cause and implications of a situation in a systematic manner.

- Conceptual thinking - developing an understanding of a situation or problem through the identification of patterns or connections between situations that are not obviously related.

- Creativity - ability to generate ideas, problem solutions, or insights that are novel and appropriate.

- Problem-solving - ability to identify key components of the problem, to collect and analyse data in order to find a solution or solutions.

- Coping with stress - stress resilience in facing failure or negative life events, ability to cope with stress of social, and organizational character, knowledge of relaxation techniques.

II. Commitment willing to do work without any compulsion, high level of attachment to the organization. Refers to an employee's emotional attachment to the organization on the basis of his or her feelings of identification with and Commitment in the organization, sense of obligation and duty to stay in the organization according to Meyer, Allen (1997):

- Motivation - degree to which person invest attention and effort in pursuits, energy a person expend in relation to work, individual's degree of willingness to exert and maintain an effort towards organizational goals, knowledge of motivational techniques.

- Proactive - taking proactive actions to avoid problems and to enhance work results.

- Persistence - maintaining the effort and constant concentration on the aim despite difficulties and discouragement. This ability is associated with the achievement of goals - the desire for success and focusing on the objectives of the team.

- Self-confidence - the self-knowledge and the skill of relying on one's own abilities, experience, knowledge and strengths; belief in one's own abilities in the face of obstacles and new challenges.

- Responsibility - anticipation and facing up consequences of behaviours, possessing personal values such as: loyalty, commitment and sincerity.

- Achievement (goal, results) orientation - refers to the employee's concern for working towards a standard of excellence.

III. Contribution - feeling of personal needs realization in the organization, sense of mission, fulfilment and self-realization:

- Meaningfulness of work - refers to the degree one's job conveys a sense of value, worthiness and purpose, amount of significance one perceive in the work according to Ejere, (2010).

- Loyalty - In general, employee loyalty can be defined as a psychological attachment or commitment to the organization and develops as a result of increase satisfaction. Satisfaction results from a process of internal evaluation, and if an employee's expectation level is met or exceeded, then satisfaction grows. Employee loyalty then develops into a generalized emotional attitude towards the organization. In other words, the more satisfied an employee is regarding his or her working environment, the more likely that he or she will develop a sense of commitment towards the organization in general according to Wan (2013). 
- Passion - is a very good relation to their job, loving one's job, experiencing personal meaning from the job.

When executing activities, a Project Manager, apart from the basic competencies, should be a manager and have all other competence related to the performance of his/her activities. These competencies can be included in the two areas and those are Contribution and Commitment. Each of these areas consists of a set of competency skills of a project manager. While is both performance and potential are important, Ulrich, Smallwood (2012) felt that a further contributor was that of a person's commitment. The key component parts of what makes up talent in an individual can be seen in in figure 1. In the figure we can see the unification of these three sets. This unification can be described as talent.

Figure 1: Final competency profile of project manager

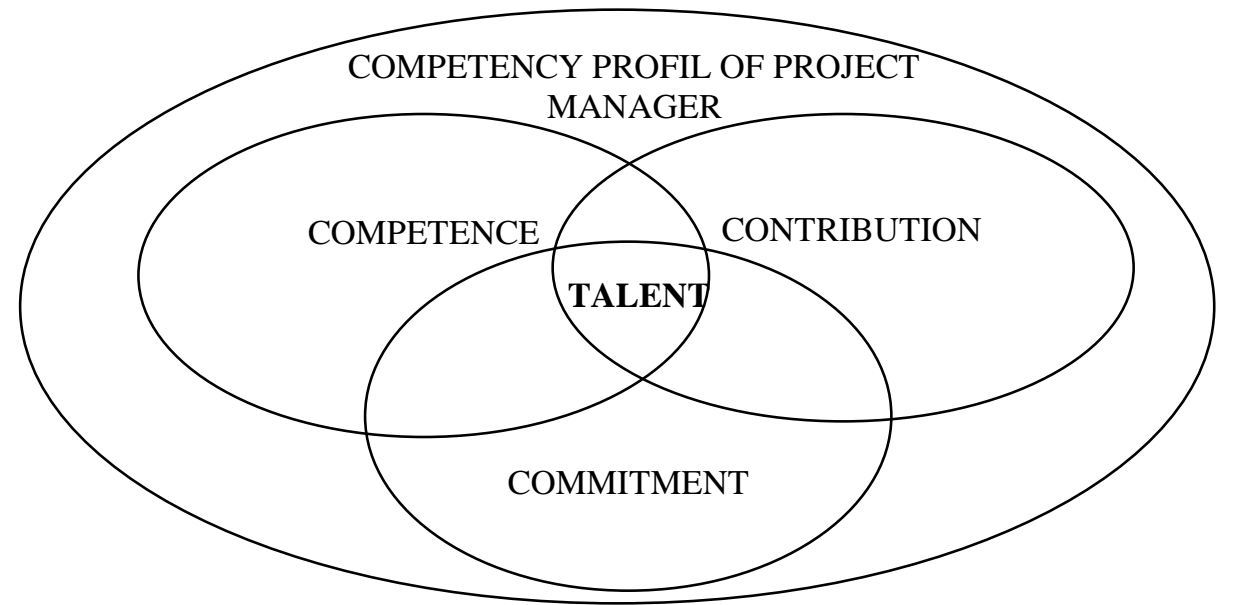

Source: own processing according to Ulrich (2011)

\section{Methods and techniques}

Department of Management and Business Administration of the Silesian University in Opava, School of Business Administration in Karvina carried out pilot research that aimed to determine the current status of the use of managerial competencies in the selected region. The aim of the pilot survey in public organizations was to find out answers to the following research question: "How is a self-worth competency profile of project managers in public organizations"? The questionnaire survey was done in the summer term of 2013 by students of the Silesian University in Opava, the School of Business Administration in Karvina. Questionnaires were obtained from 26 public organizations in the Moravian - Silesian Region. The research included executives who working in a position that deals with project management in the organization. For research were chosen organizations, which regularly producing projects. The total response group of over 40 respondents was cleaned to include only those who used and understood the competence concept and competence instruments. The questionnaire was completed at a personal meeting with the employees of the organization. The questionnaire was divided into two parts.

The first part identification of the organization, this section contained five questions (a size of organization, a business sector, a type of organizations, a job characterisation of competence, and a field of work),(see table1). 
Table 1: Identification of respondents

\begin{tabular}{|l|r|}
\hline Respondent age & $25-58$ year \\
\hline Gender & Female 42\%, Male 58\% \\
\hline Managerial experience & $2-8$ years \\
\hline Sector of business & 26 different public organizations (funded organization, municipal office) \\
\hline
\end{tabular}

The second part of the questionnaire was divided into three segments: competence, commitment and contribution. The part "competence" is created by nine competency elements, the part "commitment" contained six elements and the part "contribution" had only three elements; each of elements contained six specific questions. ${ }^{2}$ The questionnaire was split into these topic sections (see Table 2).

Table 2: Distribution of questions in the questionnaire to the individual topic sections

\begin{tabular}{|r|r|r|}
\hline \multicolumn{1}{|c|}{ Competences } & \multicolumn{1}{c|}{ Commitment } & \multicolumn{1}{c|}{ Contribution } \\
\hline Flexibility & Motivation & Meaningfulness of work \\
\hline Team working & Proactive & Loyalty \\
\hline Leadership & Persistence & Passion \\
\hline Creativity & Self-confidence & \\
\hline Communication & Responsibility & \\
\hline Coping with stress & $\begin{array}{r}\text { Achievement (goal, } \\
\text { results) orientation }\end{array}$ & \\
\hline Analytical thinking & & \\
\hline Conceptual thinking & & \\
\hline Problem-solving & & \\
\hline
\end{tabular}

Source: own processing

Individual components were summed by numbers of responses, depending on how informants answered by the scale of 1 to $5(1=$ no, $2=$ weak, $3=$ moderate, $4=$ considerable; $5=$ strong $)$. The data of questionnaire were subsequently entered into Microsoft Office 2007 Excel application for assessment. It has been calculated absolute and relative frequencies, means and standard deviations (S.D.) for the evaluation of survey results.

\section{Results}

Evaluations of the level of managerial competence in public service are based on responses obtained. The respondents have worked as project managers. The questionnaire conducted showed a self-assessment of the extent of the aforementioned statement. The results of the survey are within this post summarized and evaluated especially in the area of competence, commitment and contribution.

\subsection{Competence}

The results are shown graphically in Figure 2. From the obtained data it is apparent that employees feel most strong in the area of competence in the following areas: teamwork, leadership, flexibility, and vice versa they evaluate lifelong learning as the weakest. The largest number of responses was recorded on the level "moderate" for each question except leadership. We can conclude that the employees would need to strengthen these competencies by training that will be focused on these areas.

\footnotetext{
${ }^{2}$ Choosing competency instruments based on research „Competence and talent assessment in SMes- ComTal“"
} 
Figure 2: Competence - shares of responses in each area in accordance with the scale

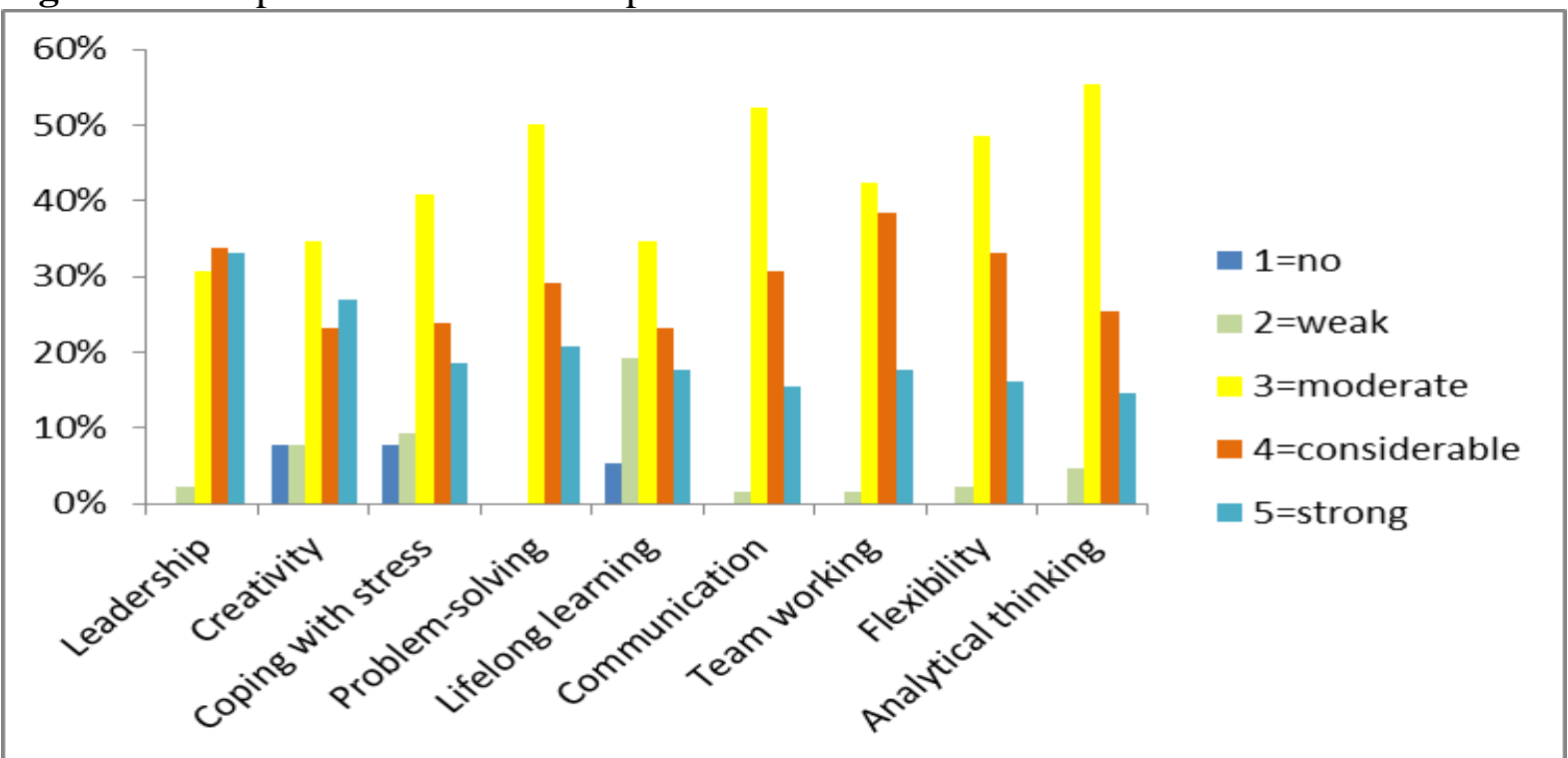

Source: own processing

We can see in table 3 the average scores awarded by respondents for each attribute are in the range of 3.48 to 3.90. It follows that the respondents evaluated at moderate. The standard deviation is the highest value at creativity (1.5).

Table 3: The results of statistical calculations factors from the area "Competence"

\begin{tabular}{|l|r|r|}
\hline \multicolumn{1}{|c|}{ Competence } & \multicolumn{1}{c|}{ Mean } & \multicolumn{1}{c|}{ S.D. } \\
\hline Leadership & 3.90 & 0.87 \\
\hline Creativity & 3.65 & 1.5 \\
\hline Coping with stress & 3.41 & 1.08 \\
\hline Problem-solving & 3.70 & 0.79 \\
\hline Lifelong learning & 3.35 & 1.08 \\
\hline Communication & 3.61 & 0.76 \\
\hline Team working & 3.76 & 0.77 \\
\hline Flexibility & 3.65 & 0.79 \\
\hline Analytical thinking & 3.48 & 0,79 \\
\hline SourCe: OWn processing
\end{tabular}

Source: own processing

\subsection{Commitment}

The answers obtained ranged unlike the degree of competence $5=$ strong and $4=$ considerable. Informants considered their strongest areas as follows: responsibility, persistence and self-confidence. In assessing the overall response to the questions we can say that in this area the informants are self-confident. Results are shown in Figure 3. 
Figure 3: Commitment - shares of responses in each area in accordance with the scale

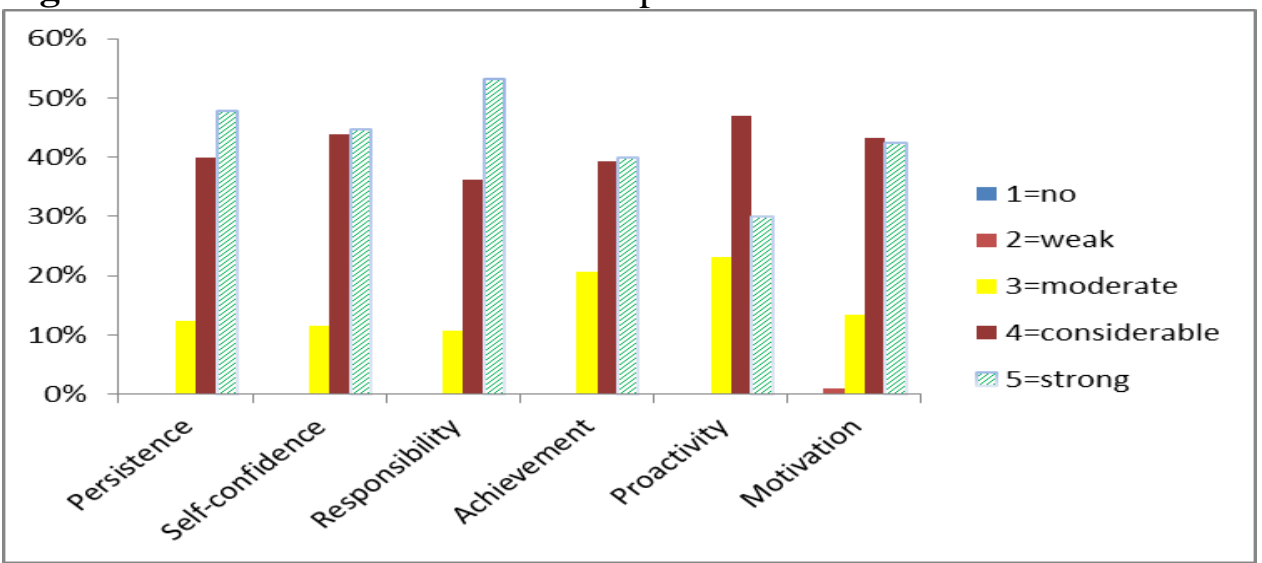

Source: own processing

The respondents evaluate the average mark in the range of 4.01 to 4.37 in the Commitment, which means that their abilities are at the level of considerable. (see table 4) The results of the standard deviations are not significant differences. The highest value was determined by a proactive approach $(0.77)$.

Table 4: The results of statistical calculations factors from the area "Commitment"

\begin{tabular}{|l|r|r|}
\hline \multicolumn{1}{|c|}{ Commitment } & Mean & \multicolumn{1}{c|}{ S.D. } \\
\hline Responsibility & 4.37 & 0.68 \\
\hline Persistence & 4.36 & 0.66 \\
\hline Self-confidence & 4.32 & 0.73 \\
\hline Achievement & 4.20 & 0.74 \\
\hline Proactivity & 4.01 & 0.77 \\
\hline Motivation & 4.35 & 0.69 \\
\hline
\end{tabular}

Source: own processing

\subsection{Contribution}

The last part of the questionnaire consisted of only three themed areas: the meaningfulness of work, passion and loyalty and there were again six questions. As for the meaningfulness of work we can see in Figure 4 that informants consider it the strongest; the questions that related to this field were answered by $55 \%$ respondents in a way that they were strong in it. In the field of loyalty respondents responded to questions most often in the total and considerable number of $56 \%$ answers.

Figure 4: Contribution - shares of responses in each area in accordance with the scale

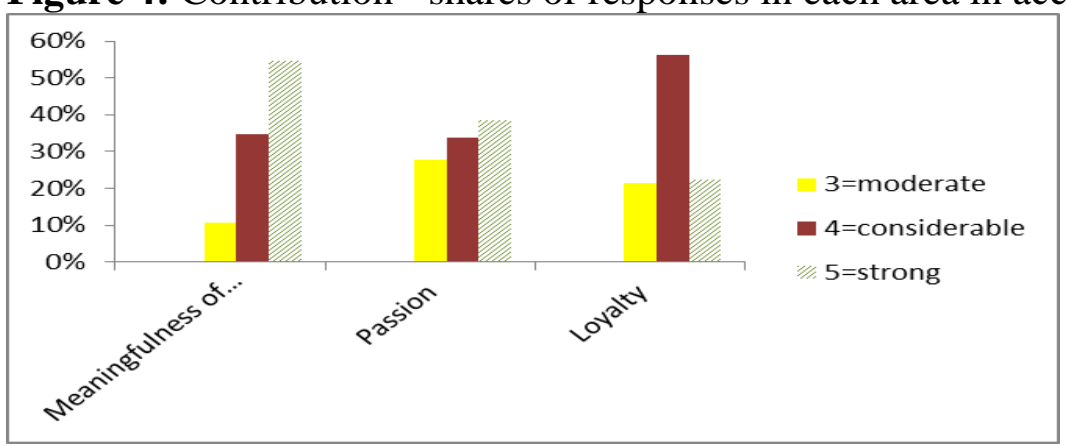

Source: own processing 
In the last area came Contribution the average ranging from 4.02 to 4.46 , the highest marks were in the area of the meaningfulness of work. (see table 5) This means that the respondent evaluate and perceive themselves at considerable. The results show that to their working position respondents have a good relationship and creating projects deemed important for their organization.

Table 5: The results of statistical calculations factors from the area "Contribution"

\begin{tabular}{|l|r|r|}
\hline \multicolumn{1}{|c|}{ Contribution } & \multicolumn{1}{c|}{ Mean } & \multicolumn{1}{c|}{ S.D. } \\
\hline Meaningfulness of work & 4.46 & 0.68 \\
\hline Passion & 4.19 & 0.78 \\
\hline Loyalty & 4.02 & 0.72 \\
\hline
\end{tabular}

Source: own processing

The final Figure 5 summarizes all the answers to all the questions in three segments Competency, Contribution and Commitment. Respondents considered contribution the strongest area. The overall response rate was strong and considerable. The second came Commitment and Competence was third. In the segment of competence it appeared that the respondents made their evaluations on moderate levels.

Table 6: Results as respondent's use of competence instruments

\begin{tabular}{|l|r|r|r|r|r|}
\hline & 1=no & 2=weak & 3=moderate & 4=considerable & 5=strong \\
\hline Competence & $2 \%$ & $5 \%$ & $43 \%$ & $29 \%$ & $20 \%$ \\
\hline Commitment & $0 \%$ & $0 \%$ & $15 \%$ & $42 \%$ & $43 \%$ \\
\hline Contribution & $0 \%$ & $0 \%$ & $17 \%$ & $42 \%$ & $40 \%$ \\
\hline
\end{tabular}

Source: own processing

Figure 5: Respondent's use of competence instruments

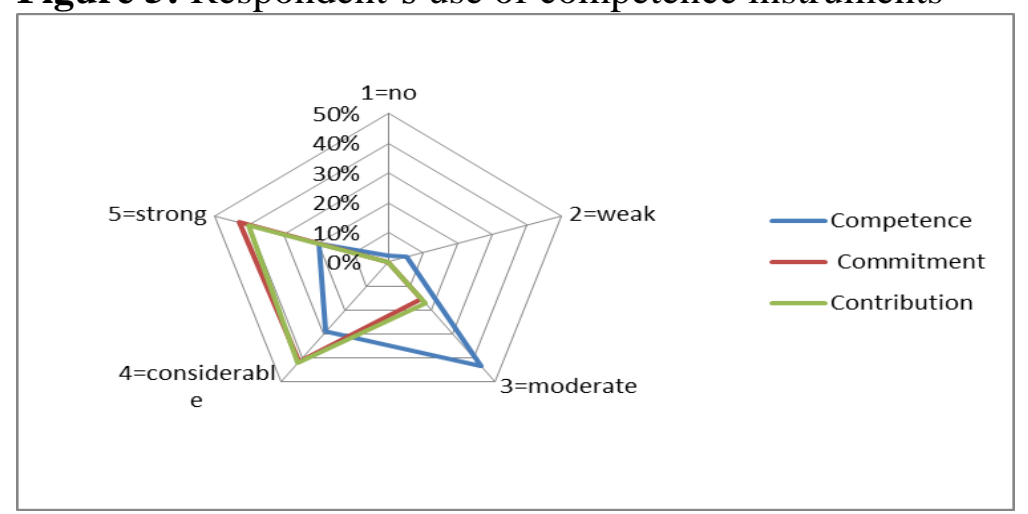

Source: own processing

\section{Conclusion}

There are plenty of other internal and external factors that may affect the work of the project manager. The managerial competence is only a personal assumption, which can be improved with the help of proper guidance, extensive training, and programmers' consultation and the introduction of necessary changes in the roles and responsibilities of human resource managers. The key question here is whether there are specific competences that some individuals will never be able to master, or whether all competences required by project managers can be taught or learnt.

The changing environment and new requirements for project managers in the public sector are the reasons that lead to the fact that the organization creates competency models. These 
models help organizations understand the competency profile of each employee, each team and the organization as a whole.

The authors aimed to analyse the current level of managerial competencies for project managers in public administration as well as describe the theoretical basis of competency management. The article presents the results of a pilot research that was carried out in public organizations in the Moravian-Silesian Region. The results of the research show that project managers considered Contribution their strength. It follows that they have a strong attachment to the tasks of the project and they are loyal to the organization. As for Competence answers prevailed on a moderate level, this means that respondents are not confident in this area of their qualities and need to strengthen these competencies. We recommend organizations to improve the quality of project managers to create a competency model that model which contain specific desired properties, which are required for this position. We regularly conduct assessments using selected methods e.g. $360^{\circ}$ degree feedback or assessment. This means there should be create the competency model after extensive consultations and training process which can be applied in a public organization. Alternatively, carry out coaching managers in an organization that would help further develop managerial competence.

Consequently there is a need to devote more attention to the human resource development strategies within the public sector in order to develop a mass of project managers able to lead and create successful projects and improve the performance of public organizations.

Theoretical findings point to a whole range of required capabilities, skills and competencies required by contemporary society not only by individuals but also by managers. To ensure that managers gain, maintain and further develop the acquired skills or competencies, offers a wide range of instruments. One of the most effective tools is lifelong learning and development.

The research presented here is only a primary research of a project manager's competence. Further studies should concentrate on specific sectors or profitable companies and also country's comparisons. To what extent do the various sectoral institutions use competence? How is it implemented? How is it evaluated?

\section{References}

[1] ARMSTRONG, M. and T. STEPHENS, 2008. Management a Leadership. Praha: Grada Publishing. ISBN 978-80-247-2177-4.

[2] BOYATZIS, R. E., 1982. The Competent Manager: A Model for Effective Performance. John Wiley \& Sons. ISBN 978-0-471-09031-1.

[3] Commission of The European Communities, 2005. [online]. [cit. 24rd July 2014]. Accessible from: http://www.ctueproject.org/all/index.php?page=referentiel\&ref= commun\&refcom $=1-1 \#$ ok

[4] DRAGANIDIS, F. and G. MENTZAS, 2006. Competency Based Management: a Review of Systems and Approaches. Information Management and Computer Security, 14(1), 51-64. ISSN 0968-5227.

[5] EJERE, E. I., 2010. Absence from Work: A Study of Teacher Absenteeism in Selected Public Primary Schools in Uyo, Nigeria. International Journal of Business \& Management, 5(9), 115-123. ISSN 1883-8119. Accessible from: http://www.ccsenet. org/journal/index.php/ijbm 
[6] ELLSTRÖM, P. E., 1997. The many meanings of occupational competence and qualification. Journal of European Industrial Training, 21(6), 266-273. ISSN 0309-0590.

[7] ENNIS, L. M., 2008. Competency Models: A Review of the Literature and The Role of the Employment and Training Administration [online]. [cit. 24rd August 2014]. Accessible from: http://www.careeronestop.org/competencymodel /info_documents/ opdrliteraturereview.pdf

[8] GAREIS, R., M. HUEMANN and A. MARTINUZZI, 2013. Project Management and Sustainable Development Principles. Vienna: Project Management Institute. ISBN 9781935589884.

[9] HORTON, S., A. HONDEGHEM and D. FARNHAM, 2002. Competency Management in the Public Sector: European Variations on a Them. IOS Press. ISBN 4274905497.

[10] International Project Management Association, 2006. [online]. [cit. 28th July 2014] Accessible from: http://www.ipma.ch/assets/ICB3.pdf

[11] LEVIN, G. and J. LEROY, 2011. Ward Program Management Complexity: A Competency Model. CRC Press Taylor a Francis group. ISBN 9781439851128.

[12] MCCLELLAND, D. C., 1973. Testing for Competence Rather Than for Intelligence. American Psychologist, 28(1), 1-14. ISSN 0003-066X.

[13] MEYER, J. P. and N. J. ALLEN, 1997. Commitment in the workplace: Theory, research, and application. Thousand Oaks, CA: Sage. ISBN 9781452263205.

[14] MOREL-CURRAN, B., 2008. The war for talent: Myths and realities [Whitepaper]. Minneapolis, MN: Korn/Ferry International.

[15] ORR, J. E., C. SNELTJES and G. DAI, 2010. Best practices in developing and implementing competency models [online]. [cit. 24rd July 2014]. Accessible from: http://www.kornferryinstitute.com/sites/all/files/documents/briefings-magazinedownload/Competency_Modeling1.pdf

[16] ULRICH, D. and N. SMALLWOOD, 2012. What is Talent? Leader to Leader, 63, 55-61. ISSN 1531-5355.

[17] WAN, L. H., 2013. Employee Loyalty at the Workplace: The Impact of Japanese Style of Human Resource Management. International Journal of Applied HRM, 3(1), 1-17. ISSN 1742-2604.

[18] WEINERT, F. E., 2001. Concept of competence: A conceptual clarification. In: D. S. RYCHEN and L. H. SALGANIK, eds. Defining and selecting key competencies. Göttingen, pp. 46-65. ISBN 978-0-88937-248-1.

[19] WHIDDETT, S. and S. HOLLYFORDE, 2003. A practical guide to competencies: How to enhance individual and organizational performance. London: CIPD. ISBN 1-84398012-6.

[20] WIECHETEK, M. and W. TALIK, 2012. Competency and Talent Profile of Employee/Team Member - ComTal - Team Member [online]. [cit. 4rd August 2014]. Accessible from: http://www.businesswest.co.uk /media/W1siZiIsIjUzMWVmZDUx NDU0NGQ0MDAwNzAwMzFkMiJdXQ/ComTalteammembercompetencyprofileFINA L.pdf 